\title{
Good Governance On Tax Amnesty
}

\author{
Ahmad Munir \\ Faculty of law \\ Universitas Islam Darul 'Ulum \\ Lamongan, Indonesia \\ ahmadmunir@unisda.ac.id
}

The concept of tax is basically a form of taxpayer contribution, either personally or agency to the state[5]. In relation to the taxpayer's income, the taxpayer's contribution must be in accordance with Act. Number 16 Year 2009 regarding Stipulation of Government Regulation in Lieu of Act. Number 5 Year 2008 regarding Fourth Amendment to Act. Number 6 Year 1983 regarding General Provision and Tax Procedure[6]. Tax revenue has not been optimal due to low tax compliance. Conditions that occur today are many people, individuals or entities that have wealth from tax evasion or tax evasion. They store or hide such property domestically and / or abroad. The depository activities of the property may be in the form of deposits, property, shares and / or invested in business activities[7].

The policy of tax amnesty is deemed to be able to gain acceptance as well as improve taxpayer compliance. Policies to stabilize state finances with amnesty programs have not done once. The Government of the Republic of Indonesia has applied Tax amnesty three times, they are in 1964, 1984, and 2016. In 1964, the Indonesian government wanted to return revolutionary funds to the state treasury through the Tax amnesty program. In 1984, Indonesia experienced an oil crisis that the government decided to extract revenues from non-oil and gas sectors, including from taxation. While in 2016, the Tax amnesty was done to cover the finance deficit[8]. The rules regarding tax amnesty have a clear legal basis that is in the form of Act. No. 11 of 2016 on Tax Amnesty[9]. The government enacted the Act. because the country's finances are experiencing a deficit. The government, with the consideration of the need situation, only thinks how to do a discretion. The question that arises is whether the tax forgiveness policy is a government-run discretion? In addition, is the tax forgiveness in accordance with the principles of good governance?

\section{RESULT AND DISCUSSION} imposition taxes or charges for the state budget of revenues and expenditures hereinafter referred as APBN[1].

Revenue from taxes is one source of state finances[2] which is really important in development financing. This is because the sources of revenue from the oil and gas sector are getting smaller in number and the acceptance of international trade activities is limited to the tariff requirements required by the World Trade Organization (WTO)[3]. In addition, it is increasingly difficult to obtain foreign debt or grants due to the global financial crisis and tight liquidity[4]. Foreign debt should not be used as a source of state revenue, because in the future, it will impact a fiscal instability which can create dependence on other countries

\section{The Power of Government Discretion in Tax Amnesty}

The study of the the rule of law needs to be discussed before the concept of tax amnesty. The term of the rule of law in Germany is "Rechtsstaat", in English with the title "rule of law", if in France has the term "Etat de droit", and in Italy with the term "Stato di dirritto"[10]. While Plato, in (429347), stated that the idea of constituional law is that: "A country should be based on rules made by the people"[11]. This idea is the developed by Socrates (1200 BC), and then continued by Aristoteles (364-322 SM), and Immanuel Kant (1742-1804). 
Whose, in the end, are known as the originator of the idea or concept of "Rechtsstaat" which see a country or a state as an instrument of protection of individual human rights[12]. The development of the idea of the rule of law produces the concept of Rechtsstaat dan the rule of law. Regarding the concept pf Rechtsstaat, Stern[13] stated that "A Rechtsstaat is a state which is bound by law and justice both with regard to the manner in which it is structured and how it acts through its organs". The rule of law uses the basis of action and as the basis for routine action by various organs based on law and justice. Then, Godefridi[14] defines that a Rechtsstaat is a state organized under rules where there is no contradiction, precisely, clearly, surely, general, and non-retroactive that prioritizes the principle of the hierarchy of norms and contains sanctions for violation of rules against the real and independent use of power from such control of power giving the order according to the rules. Stavros Zouridis[15] said that the essence embodied in the Rechtsstaat concept is concerned with the various ideologies that in legal theory, Rechtsstaat leads to the principles of law.

Sir William Wade defines "The rule of law is that everything must be done according to law"[16]. Based on Hilaire Barnet, the most important aims of the rule of law is "for ensuring limited governmental power and the protection of individual rights ...”[17]. On its developments, Stavros Zouridis stated that "The rule of law has been broadened to encompass decent administration and good governance, the separation of powers in government, the quality of legal regulations and the existence of fundamental rights"[18]. Related to the concept of Rechtsstaat and The rule of law, Stavros Zouridis confirmed that: "The rule of law and the Rechtsstaat refer to the principle of legality. This principle expresses that government is bound by its own laws"[19]. The governance in The rule of law and Rechtsstaat is limited by applicable law or legality principle. In accordance with the definition, the concept of the legal state rechtstaat or the rule of law remains the same that has a purpose to guarantee and protect human rights from the actions of state authorities or arbitrary citizens thus bringing general prosperity based on the rule of law[20].

The existence of the Tax amnesty Act is a legal rule that has three objectives. First, for the transfer of assets so as to accelerate the growth and economic restructuring that impact on increasing domestic liquidity, lower interest rates, improved rupiah exchange rate, and increased investment. Second, for a more comprehensive, integrated, and validated tax database that will encourage a more equitable taxation system reform. Third, to increase the tax revenue that can be used in financing the Development.

The tax amnesty law provides legal certainty for long-term foreign sources of funds that can be used to accelerate restructuring and economic growth. The government provides the Tax amnesty program with hope that taxes paid by taxpayers will be able to increase tax revenues. Repatriation and declaration are ways to achieve the purpose of the Tax amnesty Act. The means of repatriation are used for the transfer of taxpayers' property abroad. While the means of declaration is used to disclose taxpayers' property abroad and within the country. Returning the fund which is hided in overseas back into the country is necessary because it can make the tax officer to easily get the information about the taxpayer's wealth from the bank in the country.

Any government action in carrying out the tax affairs should be based on the rule or law. The protection of the taxpayer's rights is done through the limitation of government power. This limitation may only be made on condition that such governmental action is carried out under applicable law. Governments must take caution in making decisions based on discretion[21]. Discretion is not only for the power / legal power of the government alone but the discretion must also have a right or ideal goal so that the existence of the concept of discretion is not arbitrary[22].

The concept of discretion in Law no. 30 Year 2014 on Government Administration[23] article 1 point 9 UUAP is defined as: "Decisions and / or Acts set out and / or conducted by Government Officials to address the concrete problems faced in governing governance in terms of laws that provide choice, not regulate, incomplete or unclear, and / or governmental stagnation "Keputusan dan/atau Tindakan yang ditetapkan dan/atau dilakukan oleh Pejabat Pemerintahan untuk mengatasi persoalan konkret yang dihadapi dalam penyelenggaraan pemerintahan dalam hal peraturan perundang-undangan yang memberikan pilihan, tidak mengatur, tidak lengkap atau tidak jelas, dan/atau adanya stagnasi pemerintahan". Discretion is needed in running the government when there are issues that require resolution without the clear rules of legislation. Subsequently Article 22 of the UUAP states that only authorized Government Officials can do the discretion to make the administration process smoothly done, fill the legal void, provide legal certainty, and overcome the stagnation of government in certain circumstances for the benefit and the public interest.

The President has the legal power to submit a Draft Law on Tax Amnesty Law. The explanation in the Tax amnesty law of the first paragraph states that the state of national economic growth is decreasing, this resulting in lower tax revenue and lower financial liquidity which is used to do the administration and governance. Furthermore, the Tax Amnesty Law can fill the void of the pardon arrangement against the taxpayer who is only given a certain time, so it can provide legal certainty. Tax amnesty is an emergency because the state's finances have a deficit. So, the tax amnesty policy should be used as a means to solve the state's financial problems. Decision making on the draft amnesty tax law is based on government stagnation for wider interests. The interests of people's lives as well as the public interest or the wider community become the basis of the tax amnesty policy. Based on the objectives and scope of discretion according to UUAP, it can be concluded that the Presidential Decree filed the draft of tax amnesty law is a discretion.

\section{Good Governance in Tax Amnesty}

The advanced industrial countries incorporated in the OECD (Organization for Economic Cooperation and Development), in 1991, formulated development assistance policies linked to the issue of good governance[24]. 
Through the Conference on Good Governance in East Asia organized by Central for Strategic and International Studies (CSIS) from 17-18 November 1999 located in Jakarta, in a very short time, the issue of good governance became very popular in Indonesia. The development of good governance is based on the issue of governance in the relationship between the government and the people. Some important issues in the administration of government, among others, concerning the state economic conditions, the quality of governance, corruption, maladministration and mismanagement. The low quality of government administration, the existence of corruption, maladministration and mismanagement can be prevented by applying good governance.

Before we define what is good governance, first, we will describe the definition of governance. The concept of governance is broader than the concept of government. This is in line with the concept that formulated by Carolina G. Hernandez "Simply but, governance refers to the way in which organizations, whether in form of family, the community, the civil society, corporations, the state or regional and global organization run on managed"[25]. The concept of governance refers to the state as well as some other parties, in contrast to the concept of a government that only designates the state as an organization with the highest legal power[26]. Governance can be interpreted as the process of organizing state power in implementing the provision of public goods and services, but also the implementation of functions that have been carried out effectively and efficiently[27].

References in good governance are vary, some mention it as the Good Governance Principles (Asas-Asas Pemerintahan yang Baik /AUPB)[28], while others call it is as General Principles of Decent Governance (Asas Umum Pemerintahan yang Layak). While in The Netherland, it is called as algemene beginselen van behoorlijk bestuur.

The concept of Good Governance is the legal principle in Administration Law, included in the genus of General Principles of Proper Administration, Principles of Human Rights Administration, Principles of Public Participation

Administration and Principles of Transparent Administration[29].

United Nations Development Programme (UNDP) describes that the synergic relationship between the state, the private sector, and society should be based on the characteristics of good governance principles, as cited by the State Administration Institute, which are participation, rule of law, transparency, responsiveness, consensus orientation, equity, effectiveness and efficiency, accountability, strategic vision[30].

Characteristics of good governance principles are also proposed by Addink et al. They are properness, transparency, participation, effectiveness, accountability, and human rights[31]. Then, Henk Addink et al. define good governance as: "Good governance is a norm for the government and a right for the citizen in which more specific conditions have been formulated"[32]. Definition of good governance is started from two sides, government and citizens. The norm for government and a right for citizens applied in very special circumstances. Thus, the relationship between government and citizens is essentially in the scope of administrative law that is charged with the norms and the rights[33].

The form of good governance implementation for the government is the norm. According to Soikelli, L., "The principle of good administration is a modern legal standard which includes a rich variety of norms. The legality of administration can be seen as the point of departure for the concept of good administration along side the principles of objectivity and proportionality, the right to be heard and the taxpayers' legitimate expectations "[34.

The principle of good governance is a measure of modern law that is as an important norm from other norms. Besides the principle of objectivity and proportionality, the legality of the government can be seen as an early development of the concept of good government. The Tax Amnesty Act is a norm for the government applied in the state of the state economy which is stagnating as explained.

On the other hand, the right of a citizen, the right in the German term subjektives Recht which means right to act or not to take certain actions[35]. Article 3 of the Tax Amnesty Law states that "every Taxpayer shall be entitled to tax pardon". Taxpayers may use or do not use the right to get an amnesty. When the taxpayer uses his right, they will get a tax amnesty facility.

The relationship between Good Governance and tax forgiveness can be explained through two theories, they compensation theory and theory of functions in law and society. The compensation theory explains that Good Governance is the basis of actions taken by governments to taxpayers who get tax pardons by revealing the property and paying the ransom. Thus, they will be able to eliminate the tax payable, tax administration sanctions, and criminal sanctions in the field of taxation. According to the theory of functions in law, Good Governance is the main foundation in the Law of Administration when it comes to taking decisions or actions. Meanwhile, according to the theory of functions in society, Good Governance helps in overseeing a policy to be legitimate in society so as to achieve justice.

Based on the characteristics proposed by Hank Adink et al., To support the theory of functions in law and society, the characteristics of good governance must be met. The principle of properness is the principle of accuracy / appropriateness that is used as a tool to to create legal certainty. The principle of appropriateness / appropriateness is used by governments in state of decision-making, government free legal power, and court supervision[36]. The legalization decree of the Tax Amnesty Act gives the government the legal power to collect the ransom money from the public. When the country is in a state of economic slowdown, it is worth the means of repatriation and declaration as a means of tax amnesty.

The principle of transparency in tax amnesty is limited to openness of work / government activities. This principle is an instrument within the framework of a decision-making procedure or action involving the public with the intention that the parties concerned may know of such a decision or action, so as to participate to protect their interests by listening (meeweten), thinking (meedenken), speaking (meespreken), and 
decide (meebeslissen)[37]. One of the provisions of the principle of transparency namely Article 10 paragraph 2 of the Tax amnesty Act stating that the Taxpayer may request explanations of things that begin charging until the completion of the completeness of documents that must be attached in the Statement of Tax amnesty

Principles of participation concern with the citizens' participation in the form of oversight of government policies and government legitimacy. The legitimacy is very important in all government activities that have a direct consequence for the community, so everyone is seen as having a direct role to play in the decision-making process[38]. This principle encourages citizen participation in decision-making of the tax amnesty law through the House of Representatives in order to immediately complete the process and the problems of the government.

Effective principle in the field of administrative law is concerned with the effective implementation and effectiveness in terms of the relationship of legal norms and facts[39]. The government's decision or action to file a draft amnesty law allows them to make a choice based on the possibility of acting or not acting for the public good.

The Accountability principle is used as a positive condition of a State affairs or the implementation of state affairs by the state organizer[40]. The Accountability Principles which determine that any activity and final outcome of Repatriation and the declaration of the tax amnesty must be accountable to the public or the people. The government's action in the tax amnesty must be in accordance with the human rights so as not to be qualified as an arbitrary action[41]. Kuntjoro Purbopranoto states that the government in facing the problems that occur in public and the governance must always have a broad view and should be able to take into account the legal consequences that will occur[42]. Therefore, it is a normal basis that government action in tax amnesty should not violate human rights. Implementation of good governance in tax amnesty can prevent financial stagnation for the state and will appear trust to tax officers for taxpayers so as to prevent the occurrence of problems between the government and taxpayers.

\section{CONCLUSION}

Based on the result and discussion, we can conclude that:

1. Based on the objectives and scope of discretion according to UUAP, that the Presidential Decree filed the Act of (RUU) tax amnesty is a discretion. Decision Making of the Tax Amnesty is due to government stagnation for the wider interest. It concerns the livelihood of the people as well as the public interest or the wider community, hence it becomes the basis of the enforcement of the policy.

2. Good governance is the main foundation when making decisions or process the tax amnesty. The government's decisions and actions in tax amnesty must meet good governance which includes properness, transparency, participation, effectiveness, accountability, and human rights. With this foundation, the government, in dealing with problems in society, will be able to take a broad view and can take into account the legal consequences. Implementation of good governance in tax amnesty can prevent financial stagnation for the state and can generate trust taxpayers to tax officials so as to prevent the emergence of problems between the government and taxpayers.

\section{REFERENCES}

[1] M. Hadi, Administrasi Keuangan Republik Indonesia, Jakarta: Gaya Baru, 1981, p. 3.

[2] Undang-Undang Nomor 17 Tahun 2003 Tentang Keuangan Negara (Lembaran Negara Republik Indonesia Tahun 2003 Nomor 47, Tambahan Lembaran Negara Republik Indonesia Nomor 4286).

[3] Roy Bahl dan Richard M. Bird, "Tax Policy In Developing Countries: Looking back and forward", National Tax Journal, Vol. LXI, No. 2, 2008, p. 289.

[4] IMF, Fiscal Implementation Of The Global Economic An Financial Crisis, IMF Staff Position Note SPN/09/13, 2009.

[5] Rochmat Soemitro, Dasar-Dasar Hukum Pajak Dan Pajak Pendapatan 1944, Fourth Printing, Bandung: Eresco, 1979, p. 23

[6] Lembaran Negara Republik Indonesia Tahun 1983 Nomor 85, Tambahan Lembaran Negara Republik Indonesia Nomor 4740.

[7] Tyas Dian Anggraeni, "Keterpenuhan Prinsip Keadilan dalam UU Pengampunan Pajak (The Complience of the Principles of Justice on The Act of Pengampunan pajak)", Rechtsvinding, Vol. 5 No. 2, 2016, p. 167.

[8] Kacung Marijan, Pengampunan pajak Stimulator Pertumbuhan Ekonomi, Gelar Inovasi Guru Besar Seri II Universitas Airlangga, Surabaya, 2016, p. 5.

[9] Lembaran Negara Republik Indonesia Tahun 2016 Nomor 131, Tambahan Lembaran Negara Republik Indonesia Nomor 5899, so called as Tax Amnesty Law.

[10] Pietro Costa et al., The Rule of law, History, Theory, and Criticism, Netherlands; Springer, 2007, p. 73.

[11] Abdul Rasyid Thalib, Wewenang mahkamah Konstitusi Dan Implikasinya Dalam Sistem Ketatanegaraan Republik Indonesia, Bandung: Citra Aditya Bakti, 2006, p. 44.

[12] Ibid.

[13] Stern as cited by Joachim Wolf, Developmental and Environmental Responsibilities of the "Rechtsstaat", Potchefstroom Electronic Law Journal, Vol. 2 No. 1, 1999, p. 8.

[14] Godefridi as cited by Frank van Dun, Political Liberalism and The Formal Rechtsstaat, Article, 2004, p. 5.

[15] Stavros Zouridis, Do Pinball Politics Threaten the Rule of Law? The Credibility of the Rule of Law in an Era of Capricious Politics, Paper, No Year, p. 3.

[16] Sir William Wade, Administrative Law, Sixth Edition, United Kingdom: Clarendon Press-Oxford,1988, p. 23.

[17] Hillaire Barnet, Constitutional \& Administrative Law, London: Cavendish Publishing Limited, 2004, p. 69.

[18] Stavros Zouridis, loc. cit.

[19] Ibid.

[20] A. Mukthie Fadjar, Tipe Negara Hukum, Malang: Bayu Media, 2005, p. 41-40.

[21] F. H. Van Der Borg, G.J.M. Cartigny, Rechtsbescherming Tegen de Overheid, 4 druk, seri Staats-en Bestuursrecht 1, Nijmegen, 1983. Dalam Philipus M. Hadjon, Perlindungan Hukum Bagi Rakyat di Indonesia, Peradaban, 2007, p. 2.

[22] Krisna Darumurti, Konsep dan Asas Hukum Kekuasaan Diskresi Pemerintah, Disertasi, Universitas Airlangga, Surabaya, 2015, h. 74.

[23] Lembaran Negara Republik Indonesia Tahun 2014 Nomor 292, Tambahan Lembaran Negara Republik Indonesia Nomor 5601, so called as UUAP.

[24] Carolina G. Hernandez, "Governance Civil Society and democraty", Conference on Good governance in East Asia Realities Problems and 
Challenges, Centre for Strategic and International study bekerjasama dengan Konsrad Adenauer Foundation regional Office Manila, Jakarta, 1999, p. 1. Cited from Philipus M. Hadjon et al., Hukum Administrasi dan Good governance, Jakarta: Trisakti, 2010, p. 3

[25] Carolina G. Hernandez, Op. Cit., h. 2. Cited from Dani Elpah, Perincian dan Penormaan Asas-Asas Umum Pemerintahan yang Baik, Disertasi, Universitas Airlangga, Surabaya, 2010, p. 5.

[26] Paulus Effendie Lotulung, Hukum Administrasi dan Good governance, Jakarta: Universitas Trisakti, 2010, p. 37. Cited from Herini Siti Aisyah, Prinsip-Prinsip Hukum tentang Pengawasan dalam Sistem Hukum Keuangan Negara, Disertasi, Universitas Airlangga, Surabaya, 2013, p. 72.

[27] Sedarmayanti, Good governance (pemerintahan yang baik) dalam rangka otonomi daerah Upaya membangun organisasi efektif dan efisien melalui restrukturisasi dan pemberdayaan, Bandung: Mandar Maju, 2003, p. 4.

[28] Philipus M. Hadjon dan Tatiek Sri Djatmiati stated in their book entitled Argumentasi hukum that the most biggest discovery or invention in law of administration as in normative law is AUPB. Philipus M. Hadjon and Tatiek Sri Djatmiati, Argumentasi Hukum, Yogyakarta: Gajah Mada University Press, 2009, p. 4.

[29] G.H. Addink, Principles of Good governance Reader, Utrecht: Faculteit Rechtsgeleerheid-Universiteit Utrecht, 2003, p. 13.

[30] Lembaga Administrasi Negara dan Badan Pengawasan Keuangan dan Pembangunan, Akuntabilitas dan Good governance, Jakarta: Lembaga
Administrasi Negara dan Badan Pengawasan Keuangan dan Pembangunan, 2000. Cited from Herini Siti Aisyah, Op. Cit. p. 24.

[31] Henk Addink, Op. Cit., p. 23.

[32] Henk Addink et al., Human Rights \& Good governance, Utrecht: Sourcebook, 2010, p. 14.

[33] Abdullah, Perlindungan Hukum Bagi Wajib Pajak atas Penggunaan Wewenang Pemerintah dalam Rangka Pengawasan Pajak, Disertasi, Universitas Airlangga, Surabaya, 2013, p. 279.

[34] Soikkeli, L., "Luottamuksensuoja verotuksessa", Verotus, Asiantuntijaartikkeli, Vol. 5 No. 4, 2004. Cited from Pasquale Piston, Legal Remedies in European Tax Law, Netherlands: IBFD, 2009, p. 179.

[35] Hans Kelsen, Pure Theory of Law, California: Berkley Universty, 1978, p. 144

[36] Henk Addink, Op. Cit., p. 30-31.

[37] Siti Sundari Rangkuti, Hukum Lingkungan dan Kebijaksanaan Lingkungan Nasional, Surabaya: Airlangga University Press, 2000, p. 277.

[38] Henk Addink, Op. Cit., p. 76.

[39] Ibid., p. 95.

[40] Ibid., p. 99.

[41] A.W. Bradley and K.D. Ewing, Constitutional and Administrative Law, Pearson Education Ltd., Harlow-London, 2007, p. 736.

[42] Kuntjoro Purbopranoto, Beberapa Catatan Hukum Tata Pemerintahan dan Peradilan Administrasi Negara, Alumni, Bandung, 1975, p. 36. 